\title{
EFEKTIFITAS PEMBELAJARAN DENGAN METODE AIR (AUDITORY INTELLECTUALLY REPETITION) DALAM MENUMBUHKAN MOTIVASI BELAJAR SISWA
}

\author{
GURUH FAJAR AFRYANTO \\ Pascasarjana PMIPA, Universitas Indraprasta PGRI, Jakarta \\ Email : azwa1011@gmail.com
}

\begin{abstract}
ABSTRAK
Secara garis besar artikel ini bertujuan untuk mengetahui model pembelajaran yang diterapkan disekolah yang pada umumnya masih berpusat pada guru, yang mengakibatkan siswa merasa bosan, sehingga menyebabkan motivasi belajarnya rendah. Pembelajaran yang digunakan sekarang adalah pembelajan yang aktif, inovatif dan kreatif yaitu dengan mengembangkan pembelajaran dengan metode AIR (Auditory Intellectually Repetition). Model pembelajaran AIR (Auditory Intellectually Repetition) adalah model pembelajaran yang menganggap bahwa suatu pembelajaran akan efektif jika memperhatikan tiga hal yaitu Auditory, Intellectually, dan repetition. Auditory berarti indera telinga digunakan dalam belajar dengan cara menyimak, berbicara, presentasi, argumentasi, mengemukakan pendapat dan menanggapi. Intellectually berarti kemampuan berfikir perlu dilatih melalui latihan bernalar, mencipta, memecahkan masalah, mengkontruksi dan menerapkan. Repetition/pengulangan diperlukan dalam pembelajaran agar pemahaman lebih mendalam dan lebih luas. Siswa perlu dilatih melalui pengerjaan soal, pemberian tugas (praktek), dan quis. Sehingga dengan model pembelajaran dengan metode AIR dapat meningkatkan motivasi siswa. Motivasi adalah suatu proses untuk menggiatkan motif/daya menjadi perbuatan atau tingkah laku untuk memenuhi kebutuhan dan mencapai tujuan tertentu. Motivasi siswa dapat timbul dari dalam diri individu (motivasi intrinsik) dan dapat timbul dari luar diri siswa/ motivasi ekstrinsik.
\end{abstract}

Kata Kunci: model pembelajaran, motivasi belajar.

\section{ABSTRACT}

Generally this article aims to find out the learning model that is applied in school which is generally still centered on the teacher, that effecting students are bored, causing low learning motivation. Now learning uses is the active, innovative and creative learners is by developing learning with the AIR method (Auditory Intellectually Repetition). The Air Learning Model (Auditory Intellectually Repetition) is a learning model considers that a learning will be effective if you pay attention to three things; auditory, intellectually, and repetition. Auditory means ear senses used in learning by listening, speaking, presentations, arguments, suggesting opinions and responding. Intellectually means the ability to think needs to be trained through reasoning exercises, creating, solving problems, currying and implementing. Repetition is needed in learning so that the understanding is more profound and wider. Students need to be trained through the work of questions, practice tasks, and quis. So that with the learning model with AIR methods can increase students motivation. Motivation is a process to grow the motives/power into deeds or behavior to meet needs and achieve certain goals. Students motivation can arise from individuals (intrinsic motivation) and can arise from outside students / extrinsic motivation.

Keywords: learning model, motivation to learn.

\section{PENDAHULUAN}

Pembelajaran yang diterapkan di sekolah-sekolah saat ini pada umumnya masih berbentuk pembelajaran satu arah yakni dominasi guru dalam penyampaian materi. Akibatnya siswa merasa bosan, pasif, dan motivasi belajar rendah sehingga mengakibatkan hasil belajarnya juga rendah. Menurut Senduk Nurhadi dan Agus Gerrad Senduk (2003:13)"Fenomena rendahnya mutu pembelajaran disebabkan oleh sikap spekulatif dan 


\section{EDUCATOR : Jurnal Inovasi Tenaga Pendidik dan Kependidikan Vol. 1 No. 2 Desember 2021, e-ISSN : 2807-8659 | p-ISSN : 2807-8829}

intuitif guru dalam memilih metode dan strategi pembelajaran". Karena itu ia menyatakan bahwa "peningkatan kualitas pendidikan dapat dilakukan dengan memperbaiki kualitas pembelajaran, dan peningkatan pembelajaran ditempuh dengan meningkatkan pengetahuan tentang merancang metode-metode pembelajaran yang lebih efektif, efisien, dan memiliki daya tarik". Hal ini menunjukkan, bahwa usaha untuk meningkatkan kualitas pendidikan bukanlah permasalahan yang sederhana, tapi merupakan permasalahan yang kompleks dan saling berkaitan dengan kualitas pendidikan dan mutu guru.

Kemampuan kreativitas dan pemecahan masalah merupakan bentuk pemikiran yang sampai saat ini masih kurang mendapat perhatian dalam pendidikan formal. Seharusnya dalam kegiatan belajar mengajar, kreativitas siswa dalam memecahkan masalah itu sangat penting. Hal ini karena dengan kreativitas seorang siswa akan berusaha memecahkan suatu permasalahan dan berusaha untuk menyelesaikannya. Selain itu siswa bisa mengembangkan suatu gagasan yang dimiliki sehingga kegiatan pembelajaran bisa berjalan lancar. Hamalik (1995: 57) menyebutkan pembelajaran sebagai suatu kombinasi yang tersusun meliputi unsur manusia, material, fasilitas, perlengkapan dan prosedur yang saling mempengaruhi untuk mencapai tujuan pembelajaran. Oleh karena itu, perlu ada inovasi dalam pembelajaran matematika yang dapat meningkatkan kemampuan kreativitas siswa dalam pemecahan masalah.Berdasarkan permasalah tersebut maka dilakukan suatu penerapan model pembelajaran yaitu penerapan model pembelajaran AIR dengan menggunakan strategi pembelajaran kreatif Produk untuk meningkatkan pemecahan masalah siswa ditinjau dari kreativitas siswa. Hal ini dikarenakan kemampuan kreativitas siswa yang tinggi dalam memecahkan masalah dapat menciptakan ide atau gagasan baru. Oleh karena itu perlu disisipkan strategi pembelajaran kreatif produktif dalam model pembelajaran AIR. Hal ini karena, dalam strategi pembelajaran kreatif produktif memiliki tahapan pembelajaran yang menarik siswa untuk meningkatkanrasa ingin tahunya, karena pada dasarnya untuk menjadi kreatif seseorang harus bekerja keras, berdedikasi tinggi, antusias, serta percaya diri. Sehingga dengan menyisipkan strategi pembelajaran kreatif produk dapat menutup kekurangan dari model pembelajaran AIR.

Dengan demikian, pembelajaran yang mungkin dilakukan adalah pembelajaran yang berorientasi pemecahan masalah. Dalam pengembangan perangkat pembelajaran yang diperlukan saat ini adalah pembelajaran yang inovatif dan kreatif yaitu dengan mengembangkan pembelajaran dengan metode AIR (Auditory Intellectually Repetition).

Model pembelajaran AIR menganggap bahwa suatu pembelajaran akan efektif jika memperhatikan tiga hal yaitu Auditory, Intellectually, dan Repetition. Auditory berarti indera telinga digunakan dalam belajar dengan cara menyimak, berbicara, presentasi, argumentasi, mengemukakan pendapat dan menanggapi. Intellectually berarti kemampuan berfikir perlu dilatih melalui latihan bernalar, mencipta, memecahkan masalah, mengkontruksi dan menerapkan. Repetition pengulangan diperlukan dalam pembelajaran agar pemahaman lebih mendalam dan lebih luas. Siswa perlu dilatih melalui pengerjaan soal, pemberian tugas (praktek) dan quis.

Dengan model ini siswa dibiasakan untuk menggunakan indera telinga dan kemampuan berfikirnya untuk melakukan pemecahan masalah. Berdasarkan prinsip belajar yang dikemukakan oleh teori Thorndike ada tiga hal diantaranya : pertama hukum latihan (law of exercise) menyatakan jika proses pengulangan sering terjadi maka hubungan yang terjadi akan bersifat otomatis, kedua Law of Reading yaitu belajar akan efektif dan efisien jika dimulai dari kesiapan peserta didik, dan ketiga yaitu law of Intencity adalah belajar akan efektif dan efisien jika berlangsung dalam intensitas yang mendukung. Sehingga siswa yang diberi model pembelajaran AIR (Auditory Intellectually Repetition) ini diharapkan memiliki kemampuan untuk menyelesaikan masalah-masalah kehidupan sehari-hari. 


\section{METODE PENELITIAN}

Penelitian ini menggunakan metode penelitian deskriptif dengan pendekatan analisis kualitatif. Menurut Moleong (2007:6) "Penelitian kualitatif adalah penelitian yang bermaksud untuk memahami fenomena tentang apa yang dialami oleh subyek penelitian misalnya: perilaku, persepsi, motivasi, tindakan, dan lain lain, secara holistik, dan dengan cara deskripsi dalam bentuk kata- kata dan bahasa, pada suatu konteks khusus yang alamiah dan dengan memanfaatkan berbagai metode alamiah". Ditinjau dari apek yang diteliti, penelitian ini merupakan study kasus (case study). Studi kasus adalah bentuk penelitian yang mendalam tentang suatu aspek lingkungan sosial termasuk manusia di dalamnya.

\section{HASIL DAN PEMBAHASAN}

1. Model Pembelajaran AIR (Auditory Intellectually Repetition)

a. Pengertian model pembelajaran AIR (Auditory Intellectually Repetition)

Menurut Model pembelajaran adalah pola interaksi murid dengan guru didalam kelas yang menyangkut strategi, pendekatan, metode dan teknik pembelajaran yang diterapkan dalam pelaksanaan kegiatan belajar mengajar di kelas (Mudjiono dan Dimyati, 2002).. Model pembelajaran yang ada pada umumnya sangat banyak, salah satunya adalah model pembelajaran AIR ( Auditory Intellectually Repetition).

Model pembelajaran AIR (Auditory Intellectually Repetition) adalah model pembelajaran yang menganggap bahwa suatu pembelajaran akan efektif jika memperhatikan tiga hal yaitu Auditory, Intellectually, dan repetition. Auditory berarti indera telinga digunakan dalam belajar dengan cara menyimak, berbicara, presentasi, argumentasi, mengemukakan pendapat dan menanggapi. Intellectually berarti kemampuan berfikir perlu dilatih melalui latihan bernalar, mencipta, memecahkan masalah, mengkontruksi dan menerapkan. Repetition pengulangan diperlukan dalam pembelajaran agar pemahaman lebih mendalam dan lebih luas. Siswa perlu dilatih melalui pengerjaan soal, pemberian tugas ( praktek ), dan quis. (Nurhadi \& Senduk, Op. Cit.hlm.64)

Teori yang mendukung model pembelajaran AIR (Auditory Intellectually Repetition) salah satunya adalah aliran psikologis tingkah laku serta pendekatan pembelajaran matematika berdasarkan faham kontruktivisme. Tokoh-tokoh dalam aliran psikologis tingkah laku diantaranya adalah Ausubel dan Erward L. Thorndike (Suherman, 2001) dikenal dengan belajar bermakna dan pentingnya pengulangan sebelum pembelajaran dimulai. Teori Thorndike (Suherman, 2001) salah satunya mengungkapkan the law of exercise (hukum latihan) yang pada dasarnya menyatakan bahwa stimulus dan respons akan memiliki hubungan satu sama lain secara kuat jika proses pengulangan sering terjadi. Semakin banyak kegiatan pengulangan dilakukan maka hubungan yang terjadi akan semakin bersifat otomatis (Suherman:2001)

\section{b. Pendekatan kontruktivisme sebagai dasar metode pembelajaran AIR (Auditory Intellectually Repetition)}

Penerapan model pembelajaran AIR (Auditory Intellectually Repetition) pada pokok bahasan turunan yang akan dilakukan penulis adalah dengan menggunakan pendekatan kontruktivis. Menurut Sagala (2006:74) keunggulan pendekatan kontruktivis yang menekankan pada proses ini adalah memberikan bekal cara memperoleh pengetahuan dan masa depan yang bersifat kreatif, siswa berperan aktif dan dapat meningkatkan ketrampilan berfikir dan cara memperoleh pengetahuan.

\section{a) Auditory}

Auditory berarti indera telinga yang digunakan untuk belajar dengan cara menyimak, berbicara, presentasi, argumentasi, mengemukakan pendapat dan menanggapi. Liksman (Alhamadi, 2006) mengartikan auditory dalam konteks 
pembelajaran sebagai belajar dengan mendengar, berbicara dan juga mendiskusikan ide dan pemikiran kepada orang lain.

Menurut Tiel (2004: 28) masuknya informasi melalui auditory bentuknya harus berurutan, teratur dan membutuhkan konsentrasi yang baik agar informasi yang masuk dapat ditangkap dengan baik yang kemudian akan diproses dalam otak. Mendengar merupakan salah satu aktivitas belajar, karena tidak mungkin informasi atau materi yang disampaikan secara lisan oleh guru dapat diterima dengan baik oleh siswa jika tidak melibatkan indera telinganya untuk mendengar.

Dalam kegiatan pembelajaran sebagian besar proses interaksi siswa dengan guru dilakukan dengan komunikasi secara lisan dan melibatkan indera telinga. Guru harus mampu untuk mengkondisikan siswa agar mengoptimalkan indera telinganya, sehingga koneksi antara telinga dan otak dapat dimanfaatkan secara optimal. Guru dapat meminta siswa untuk menyimak, mendengar, berbicara, presentasi, berargumen, mengemukakan pendapat dan menanggapi sehingga menciptakan suasana belajar yang aktif.

Menurut Meier (2006:92) ada beberapa gagasan untuk meningkatkan penggunaan auditory dalam belajar, diantaranya :

(a) Mintalah siswa untuk berpasangan, membincangkan secara terperinci apa yang baru mereka pelajari dan bagaimana

menerapkannya.

(b) Mintalah siswa untuk mempraktekkan suatu ketrampilan atau memperagakan suatu konsep sambil mengucapakan secara terperinci apa yang sedang mereka kerjakan.

(c) Mintalah siswa untuk berkelompok dan berbicara saat penyusunan pemecahan masalah.

\section{b) Intellectually}

Intellectually yaitu kemampuan berfikir perlu dilatih melalui latihan bernalar, mencipta, memecahkan masalah, mengkontruksi dan menerapkan. Meier (2002:99) menafsirkan intellectually sebagai dari yang merenung, mencipta, memecahkan masalah, dan membangun makna. Sabana (Apriani, 2008) berpendapat bahwa proses berfikir adalah proses aktifnya indera mata, telinga dan rasa akan diolah dalam otak melalui peristiwa listrik yang akan merangsang sekaligus mengaktifkan sel-sel otak.

Meier (2002:100) mengemukakan bahwa aspek dalam Intellectually dalam belajar akan terlatih jika siswa dilibatkan dalam aktifitas memecahkan masalah, menganalisis pengalaman, mengerjakan perencanaan strategis, melahirkan gagasan kreatif, mencari dan menyaring informasi, menemukan pertanyaan menciptakan model mental, menciptakan gagasan baru, menciptakan makna pribadi, dan meramalkan implikasi suatu gagasan. Sehingga guru harus mampu merangsang, mengarahkan, memelihara dan meningkatkan intensitas proses berfikir siswa demi tercapainya motivasi belajar siswa yang maksimal.

\section{c) Repetition}

Trianto (2007 : 22) mengemukakan masuknya informasi ke dalam otak yang diterima melalui proses penginderaan akan masuk ke dalam memori jangka pendek, penyimpanan informasi dalam memori jangka pendek memiliki jumlah dan waktu yang terbatas. Proses mempertahankan informasi ini dapat dilakukan dengan adanya kegiatan pengulangan informasi yang masuk ke dalam otak . dengan adanya latihan dan pengulangan akan membantu dalam proses mengingat, karena semakin lama informasi itu tinggal dalam memori jangka pendek, maka semakin besar 
kesempatan memori tersebut ditransfer ke dalam memori jangka panjang. Hal ini sejalan dengan teori Ausubel mengenai pentingnya pengulangan.

Pengulangan yang dilakukan tidak berarti dilakukan dengan bentuk pertanyaan ataupun informasi yang sama, melainkan dalam bentuk informasi yang berfareatif sehingga tidak membosankan. Dengan pemberian soal dan tugas, siswa akan mengingat informasi-informasi yang diterimanya dan terbiasa untuk menyelesaikan permasalahan-permasalahan matematis.

\section{c. Langkah-langkah strategi pembelajaran AIR yaitu :}

1) siswa dikelompokkan menjadi beberapa kelompok yang heterogen.

2) Guru membagikan LKS.

3) guru mengarahkan dan memberi petunjuk cara penyelesaian konsep yang ada di LKS dengan cara eksplorasi media pembelajaran (auditory).

4) secara berpasangan siswa tampil di depan berbagi ide mendemonstrasikan media untuk memecahkan permasalahan (Intellectualy).

5) siswa mengerjakan lembar permasalahan secara individu dengan cara mengajukan pertanyaan (Intellectualy).

6) diskusi kelompok (sharing) berbicara, mengumpulkan informasi, membuat model, mengemukakan gagasan untuk memecahkan permasalahan yang diajukan (Intellectualy).

7) wakil dari kelompok tampil di depan kelas untuk mempresentasikan hasil kerja kelompok, kelompok lain menanggapi, melengkapi, dan menyetujui kesepakatan (Intellectualy).

8) seorang siswa wakil dari kelompok kawan menyimpulkan (Intellectualy).

9) kegiatan penutupan siswa diberi kuis (Repetition).

\section{Motivasi Belajar Siswa}

(Alya 2009:468) Motivasi adalah suatu proses untuk menggiatkan motif / daya menjadi perbuatan atau tingkah laku untuk memenuhi kebutuhan dan mencapai tujuan tertentu. Dalam hal belajar motivasi diartikan sebagai keseluruhan daya penggerak dalam diri siswa untuk melakukan serangkaian kegiatan belajar guna mencapai tujuan yang telah ditetapkan. Tugas guru adalah membangkitkan motivasi anak sehingga ia mau melakukan serangkaian kegiatan belajar. Motivasi siswa dapat timbul dari dalam diri individu (motivasi intrinsik) dan dapat timbul dari luar diri siswa/ motivasi ekstrinsik (Uzer Usman, 2008).

Motivasi instrinsik merupakan motivasi yang timbul sebagai akibat dari dalam diri individu tanpa ada paksanan dan dorongan dari orang lain, misalnya anak mau belajar karena ingin memperoleh ilmu pengetahuan atau ingin mendapatkan keterampilan tertentu, ia akan rajin belajar tanpa ada suruhan dari orang lain. Sebaliknya motivasi ekstrinsik timbul sebagai akibat pengaruh dari luar individu, apakah karena ajakan, suruhan atau paksaan dari orang lain sehingga dengan kondisi yang demikian akhirnya ia mau belajar.

Kegiatan untuk menumbuhkan motivasi belajar siswa bukanlah hal mudah untuk dilakukan. Rendahnya kepedulian orang tua dan guru, merupakan salah satu penyebab sulitnya menumbuhkan motivasi belajar anak.. Fakta yang terjadi selama ini menunjukan bahwa ketika ada permasalahan tentang rendahnya motivasi belajar siswa, guru dan orang tua terkesan tidak mau peduli terhadap hal itu, guru membiarkan siswa malas belajar dan orang tua pun tidak peduli dengan kondisi belajar anak. Maka untuk menumbuhkan motivasi belajar siswa orang tua dan guru perlu mengetahui penyebab rendahnya motivasi belajar siswa dan faktor-faktor yang mempengaruhinya. 


\section{a. Faktor-faktor yang menyebabkan rendahnya motivasi belajar siswa} diantaranya adalah sebagai berikut:

a) Metode mengajar guru.

Metode dan cara-cara mengajar guru yang monoton dan tidak menyenangkan akan mempengaruhi motivasi belajar siswa.

b) Tujuan kurikulum dan pengajaran yang tidak jelas.

c) Tidak adanya relevansi kurikulum dengan kebutuhan dan minat siswa.

d) Latar belakang ekonomi dan sosial budaya siswa.

Sebagian besar siswa yang berekonomi lemah tidak mempunyai motivasi yang kuat untuk belajar dan melanjutkan pendidikan ke jenjang yang lebih tinggi. Kebanyak masyarakat di sebagai seorang petani, rata rata kebanyakan dari orangtua atau dari anak-anaknya sendiri memilih membantu orangtua daripada sekolah, bahkan sebagaian besar lebih memilih merantau untuk bekerja di kota kota besar.

e) Kemajuan teknologi dan informasi. Siswa hanya memanfaatkan produk teknologi dan informasi untuk memuaskan kebutuhan kesenangan saja.

f) Merasa kurang mampu terhadap mata pelajaran tertentu, seperti matematika, dan bahasa inggris.

g) Masalah pribadi siswa baik dengan orang tua, teman maupun dengan lingkungan sekitarnya.

Raymond dan Judith (2004:24) mengungkapkan ada empat pengaruh utama dalam motivasi belajar seorang anak, yaitu:

Masing-masing kelompok atau etnis telah menetapkan dan menyatakan secara tidak langsung nilai-nilai yang berkenaan dengan pengetahuan baik dalam pengertian akademis maupun tradisional. Nilai-nilai itu terungkap melalui pengaruh agama, undang-undang politik untuk pendidikan serta melalui harapanharapan orang tua yang berkenaan dengan persiapan anak-anak mereka dalam hubungannya dengan sekolah. Hal-hal ini akan mempengaruhi motivasi belajar anak.

a) Keluarga.

Berdasarkan penelitian orang tua memberi pengaruh utama dalam memotivasi belajar seorang anak. Pengaruh mereka terhadap perkembangan motivasi belajar anak-anak memberi pengaruh yang sangat kuat dalam setiap perkembangannya dan akan terus berlanjut sampai habis masa SMA dan sesudahnya.

b) Sekolah.

Ketika sampai pada motivasi belajar, para gurulah yang membuat sebuah perbedaan. Dalam banyak hal mereka tidak sekuat seperti orang tua. Tetapi mereka bisa membuat kehidupan sekolah menjadi menyenangkan atau menarik. Dan kita bisa mengingat seorang guru yang memenuhi ruang kelas dengan kegembiraan dan harapan serta membukakan pintu-pintu kita untuk menemukan pengetahuan yang mengagumkan.

c) diri anak itu sendiri.

Murid-murid yang mempunyai kemungkinan paling besar untuk belajar dengan serius, belajar dengan baik dan masih bisa menikmati belajar, memiliki perilaku dan karakter pintar, berkualitas, mempunyai identitas, bisa mengatur diri sendiri sudah pasti mempengaruhi motivasi belajarnya.

Dilihat dari peranannya, maka orang tua dan guru paling berpengaruh dalam rangka memotivasi belajar siswa. Kerja sama antara kedua komponen ini akan menghasilkan kekuatan luar biasa yang bisa menumbuhkan motivasi belajar anak. Untuk menghasilkan kolaborasi dalam rangka mencapai tujuan yang baik maka pola kerja sama antara ke duanya harus dirancang sedemikian rupa. Kekuatan dan kelemahan yang dimiliki oleh orang tua dan guru harus teridentifikasi dengan jelas. 
Karena dengan memahami kekuatan dan kelemahan guru dan orang tua akan dapat membuat rancangan yang tepat untuk menumbuhkan motivasi anak.

\section{b. Ciri- Ciri Guru yang Bisa Memotivasi Siswa}

Salah satu ciri guru yang bisa memotivasi adalah antusiasme, mereka peduli dan paham dengan apa yang diajarkannya dan mengkomunikasikannya dengan murid bahwa apa yang sedang mereka pelajari itu penting. Ia memberikan teladan yang dapat menjadi inspirasi bagi siswanya.

c. Ciri-ciri guru yang berkualitas dan bisa memotivasi siswa adalah guru yang melakukan hal-hal sebagai berikut :

a) Menjadi manajer yang baik yang mampu merencanakan, mengelola, mengorganisasikan serta mengevaluasi kelasnya, murid-murid akan merasa aman dan nyaman bersamanya

b) Fasilitator yang memperlakukan semua siswa mendapatkan kesempatan untuk belajar dan bertanggungjawab.

S. Linuwih*, N. O. E. Sukwati (2014). Dalam jurnal Efektivitas Model Pembelajaran Auditory Intellectually Repetition (AIR) Terhadap Pemahaman Siswa Pada Konsep Energi Dalam, diperoleh hasil dan pembahasan sebagai berikut

Langkah-langkah strategi pembelajaran Auditory Intellectually Repetition (AIR) yaitu: (1) siswa dibagi menjadi beberapa kelompok yang heterogen, masing-masing kelompok terdiri atas 4-5 anggota, (2) siswa mendengarkan dan memperhatikan penjelasan dari guru, (3) setiap kelompok mendiskusikan tentang materi yang mereka pelajari dan menuliskan hasil dari hasil diskusi tersebut (Auditory), (4) masingmasing kelompok berdiskusi untuk menyelesaikan masalah (Intellectualy), (6) Wakil dari kelompok tampil di depan kelas untuk mempresentasikan hasil kerja kelompok, sedangkan kelompok yang lain menanggapi, melengkapi, dan menyetujui kesepakatan (Intellectualy), (7) Setelah selesai berdiskusi, siswa mendapat pengulangan materi dengan cara mendapatkan kuis secara individu dan tugas rumah (Repetition).

\section{Pemahaman Konsep}

Uji peningkatan pemahaman konsep fisika siswa pada bab termodinamika dilakukan dengan menggunakan uji Gain. Uji gain ini digunakan umtuk melihat ada atau tidaknya peningkatan pemahaman konsep siswa. Hasil pretest dan posttest siswa kelas eksperimen dan kelas kontrol dapat dilihat pada Tabel 1. Melalui uji Gain yang ternormalisasikan, peningkatan pemahaman siswa pada kelas eksperimen sebesar 0,77 yang termasuk kriteria tinggi, sedangkan peningkatan pemahaman siswa pada kelas kontrol sebesar 0,68 yang termasuk kriteria sedang. Menurut Ainia et al. (2012), akibat dari penekanan ketiga aspek dalam pembelajaran AIR adalah siswa memiliki kemampuan yang lebih dalam pemahaman, kreativitas dan keaktivan dalam pembelajaran, kemampuan memecahkan masalah dan daya ingat yang kuat. Selain peningkatan pemahaman konsep siswa, dalam penelitian ini dihitung pula peningkatan tiap indikator soal pretest/posttest. Hasil peningkatan tiap indikator soal pretest/ posttest.dapat dilihat pada Gambar 1. 


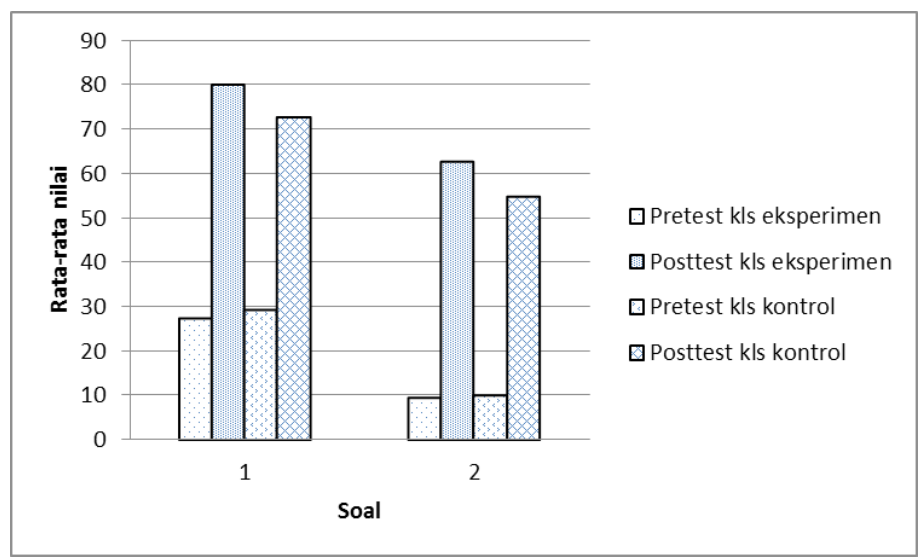

Gambar 1. Hasil Tes

Berdasarkan Gambar 1 di atas terlihat bahwa terjadi peningkatan yang signifikan antara hasil pretest dan posttest. Hal tersebut dikarenakan siswa masih kebingungan dalam menjawab soal pada saat pretest.

Permasalahan yang terjadi pada saat siswa menjawab soal nomor satu adalah siswa masih bingung untuk menentukan tanda positif atau negatif dalam perhitungan usaha. Siswa sering terjebak dalam menentukan tanda usaha tersebut sehingga mempengaruhi perhitungan. Perjanjian tanda usaha dalam perhitungan sudah ditentukan yaitu usaha bertanda positif jika sistem melakukan usaha terhadap lingkungan dan usaha bertanda negatif jika sistem menerima usaha dari lingkungan. Kesalahan yang sering terjadi yaitu siswa menganggap usaha bertanda negatif jika sistem melakukan usaha terhadap lingkungan karena sistem akan kekurangan usaha, begitupun sebaliknya karena siswa menganggap bahwa sistem yang menerima usaha dari lingkungan maka usahanya akan bertambah sehingga tanda pada usaha adalah positif.

Tabel 1. Hasil Belajar Kognitif Siswa

\begin{tabular}{llccccc}
\hline \multirow{2}{*}{ No } & \multirow{2}{*}{ Hasil Tes } & \multicolumn{2}{c}{ Kelas Eksperimen } & & \multicolumn{2}{c}{ Kelas Kontrol } \\
\cline { 3 - 4 } & & Pretest & Posttest & & P Pretest & Pos Posttest \\
\hline 1 & Nilai Terendah & 18 & 64 & & 14 & 60 \\
2 & Nilai Tertinggi & 66 & 100 & & 66 & 100 \\
3 & Nilai Rata-Rata & 38,88 & 85,81 & & 37,81 & 80,38 \\
4 & Peningkatan (Uji Gain) & \multicolumn{2}{c}{0,77 (tinggi) } & & \multicolumn{2}{c}{0,68 (sedang) } \\
\hline
\end{tabular}

Tabel 2. Persentase Ketuntasan Klasikal pada Kelas Eksperimen dan Kontrol

\begin{tabular}{llcc}
\hline Kelas & $\mathbf{n}$ & $\mathbf{x}$ & $\begin{array}{c}\text { Presentase Ketuntasan } \\
\text { klasikal }\end{array}$ \\
\hline Eksperimen & 32 & 30 & $93,75 \%$ \\
Kontrol & 32 & 29 & $90,63 \%$ \\
\hline
\end{tabular}

Permasalah yang terjadi pada nomor 2 adalah siswa kesulitan untuk menyelesaikan soal karena siswa bingung dalam mengawali perhitungan atau penyelesaian. Siswa cenderung berpikir jika persamaan yang digunakan dalam menyelesaikan soal adalah persamaan atau rumus-rumus yang baru diajarkan. Mereka tidak terbiasa untuk megingat kembali persamaan atau rumus yang telah lama mereka dapat sehingga mereka kesulitan untuk mencari besaran yang belum diketahui nilainya. Hal tersebut mengakibatkan siswa tidak dapat mengerjakan soal yang diberikan. 


\section{Ketuntasan Klasikal}

Data untuk menghitung ketuntasan klasikal ini didapat dari hasil posttest. Persentase ketuntasan klasikal kelas eksperimen dan kelas kontrol dapat dilihat pada Tabel 2. Berdasarkan analisis yang telah dilakukan, rata-rata hasil belajar siswa pada kelas eksperimen adalah sebesar 85,81 , sedangkan rata-rata hasil belajar siswa pada kelas kontrol adalah sebesar 80,38. Berdasarkan hasil tersebut, ketuntasan klasikal pada kelas ekperimen sebesar 93,75\%, sedangkan ketuntasan klasikal pada kelas kontrol sebesar 90,63 \%. Ketuntasan klasikal pada kelas eksperimen lebih tinggi daripada kelas kontrol. Hasil dalam penelitian ini sejalan dengan hasil penelitian yang dilakukan oleh Ainia et al. (2012) yang menyatakan bahwa prestasi belajar siswa dengan menggunakan model pembelajaran AIR lebih baik dari siswa yang dikenai model konvensial dan Rohmayati et al. (2013) yang menyatakan bahwa hasil belajar siswa yang mendapatkan pembelajaran dengan model AIR lebih baik daripada siswa yang mendapatkan pelajaran dengan model reciprocal teaching.

\section{Aktivitas Siswa}

Data hasil aktivitas siswa diperoleh melalui lembar observasi selama diskusi dan proses pembelajaran berlangsung. Pada aktivitas siswa ini, ada empat aspek yang diamati oleh peneliti. Empat aspek tersebut adalah sebagai berikut:

1. Perhatian siswa saat pembelajaran

2. Keberanian siswa dalam mengemukakan pendapat

3. Keberanian siswa dalam bertanya

4. Menghargai pendapat orang lain.

\begin{tabular}{cc} 
Tabel 3. Klasifikasi Kriteria & Observasi \\
\hline Persentase Aktivitas Siswa & Kriteria \\
\hline $81,25 \%<N \leq 100 \%$ & Sangat aktif \\
$62,50 \%<N \leq 81,25 \%$ & Aktif \\
$43,75 \%<N \leq 62,50 \%$ & Kurang aktif \\
$25 \%<N \leq 43,75 \%$ & Sangat kurang \\
& aktif \\
\hline
\end{tabular}

Hasil pengamatan keempat aspek tersebut dapat dilihat pada Tabel 4.

Pada Tabel 4 dapat dilihat bahwa persentase aktivitas siswa pada kelas eksperimen sebesar $63,19 \%$ yang termasuk kriteria aktif, sedangkan aktivitas siswa pada kelas kontrol sebesar 59,29\% yang termasuk kriteria kurang aktif. Berdasarkan hasil tersebut, terlihat bahwa aktivitas siswa pada kelas eksperimen lebih tinggi daripada kelas kontrol. Aktivitas siswa pada penelitian ini sejalan dengan penelitian yang dilakukan oleh Fauzi (2013) yang menyatakan bahwa pembelajaran dengan menggunakan pembelajaran kooperatif tipe STAD dapat membuat aktivitas siswa berkategori baik dalam pembelajaran.

Tabel 4. Presentase Aktivitas Siswa pada Kelas Eksperimen dan Kontrol

\begin{tabular}{lccccc}
\hline Kelas & \multicolumn{4}{c}{ Aspek } & Klasikal \\
\cline { 2 - 5 } & 1 & 2 & 3 & 4 & \\
\hline Ekperimen & 73.96 & $57.64 \%$ & 57.9 & 63.19 & 63.19 \\
& $\%$ & & $9 \%$ & $\%$ & $\%$ \\
Kontrol & 62.85 & $55.21 \%$ & 61.4 & 57.64 & 59.29 \\
& $\%$ & & $6 \%$ & $\%$ & $\%$ \\
\hline
\end{tabular}




\section{KESIMPULAN}

Model pembelajaran adalah pola interaksi murid dengan guru didalam kelas yang menyangkut strategi, pendekatan, metode dan teknik pembelajaran yang diterapkan dalam pelaksanaan kegiatan belajar mengajar di kelas. Model pembelajaran yang ada pada umumnya sangat banyak, salah satunya adalah model pembelajaran AIR (Auditory Intellectually Repetition).

Model pembelajaran AIR (Auditory Intellectually Repetition) adalah model pembelajaran yang menganggap bahwa suatu pembelajaran akan efektif jika memperhatikan tiga hal yaitu Auditory, Intellectually, dan repetition. Auditory berarti indera telinga digunakan dalam belajar dengan cara menyimak, berbicara, presentasi, argumentasi, mengemukakan pendapat dan menanggapi. Intellectually berarti kemampuan berfikir perlu dilatih melalui latihan bernalar, mencipta, memecahkan masalah, mengkontruksi dan menerapkan. Repetition pengulangan diperlukan dalam pembelajaran agar pemahaman lebih mendalam dan lebih luas. Siswa perlu dilatih melalui pengerjaan soal, pemberian tugas (praktek), dan quis.

Guru yang bisa memotivasi adalah antusiasme, mereka peduli dan paham dengan apa yang diajarkannya dan mengkomunikasikannya dengan murid bahwa apa yang sedang mereka pelajari itu penting. Ia memberikan teladan yang dapat menjadi inspirasi bagi siswanya.

\section{DAFTAR PUSTAKA}

Alya Qonita. (2009). Kamus Besar Bahasa Indonesia. Untuk Sekolah Dasar, Jakarta, PT Indah Jaya Adi Pratama.

Alhamadi. (2004). Pembelajaran Kontekstual. Malang.UM PRESS.

Judith \& Raymond. (2004). Psikologi Pendidikan, Yogyakarta:FIP Uiversitas Negeri Yogyakarta.

Mudjiono drs \& Dimiyati. (2002). Belajar dan Pembelajaran. Jakarta, PT Rineka Cipta.

Meier. (2002). Kualitas dan Hasil Belajar Biologi. Surabaya: Universitas Negeri Surabaya.

Meier. (2002). Kualitas dan Hasil Belajar Biologi. Surabaya: Universitas Negeri Surabaya.

Nurhadi dan Agus Gerrad Senduk. (2003). Pembelajaran Kontekstual (Contextual Teaching and learning/ CTL) Dan Penerapannya Dalam KBK. Malang: UM PRESS.

Suherman. (2001). Bimbingan dan Konseling. Jakarta : Dirjen Dikti Depdikbud.

Suherman. (2001). Bimbingan dan Konseling, Jakarta : Dirjen Dikti Depdikbud.

Sagala. (2006). Meningkatkan Ketrampilan Berfikir. Jakarta : Rineka Cipta,.

S. Linuwih, N. O. E. Sukwati (2014). Efektivitas Model Pembelajaran Auditory Intellectually Repetition (Air) Terhadap Pemahaman Siswa Pada Konsep Energi Dalam. 10 (2), 158-162, from http:// doi.org/ 10.15294/jpfi-v10i2-3352

Tiel. (2004). Proses Pengajaran. Yogyakarta: Amarta. 